\title{
Peranan Asuransi Dalam Pengiriman Barang Impor Menggunakan Air Freight Forwading
}

\section{The Role of Insurance in Shipping Imported Goods Using Air Freight Forwarding}

\author{
Lilik Suryaningsih ${ }^{1 *}$ \\ ${ }^{1}$ Sekolah Tinggi Penerbangan AVIASI, Jakarta, Indonesia \\ *Penulis koresponden: lik_sryngsh@yahoo.co.id
}

\begin{abstract}
ARTICLE INFO
PBJ use only:

Received date 20 Juni 2020

Revised date 15 Juli 2020

Accepted date 2 September 2020
\end{abstract}

\begin{abstract}
The role and activities of the Freight Forwarder company or Air Ship Cargo Expedition are very important because it makes it easier for exporters and importers in export-import management services. For this reason, it is necessary to have an understanding and knowledge from the general public and related parties regarding this service, especially in shipping goods by sea. So that it is hoped that the functions and responsibilities of expedition services as an economic means of realizing an efficient, precise and safe delivery management system and arrangement of goods (by utilizing information and technology systems) Many Freight Forwarders act as operators and are fully responsible for carrying out the transportation even though they do not have their own ship. What is meant by operator here is BHI (Indonesian Legal Entity) which carries out service business activities for cargo and goods aircraft in the airport hangar in order to support transportation activities by air. The role and activities of Freight Forwarding companies are very important because it makes it easier for exporters and importers in export - import management services. The activities carried out by Freight Forwarding are an integral part that cannot be eliminated. The information and strategy for managing documents and methods of delivery are intended to provide services or management of all activities required for the delivery, transportation and delivery of goods by using multimodal transport, either by land, sea or air.
\end{abstract}

Keywords : Insurance; Imported Goods: Air Freight Forwarding 


\begin{abstract}
ABSTRAK
Peran dan kegiatan perusahaan Freight Forwarder atau Ekspedisi Muatan Kapal Udara menjadi sangat penting karena memudahkan bagi para eksportir maupun importir dalam jasa pengurusan ekspor-impor. Untuk itu perlunya pemahaman dan pengetahuan dari khalayak umum maupun pihak yang terkait mengenai jasa ini khususnya dalam kegiatan pengiriman barang melalui laut. Sehingga diharapkan fungsi dan tanggung jawab jasa ekspedisi sebagai sarana ekonomi dalam mewujudkan sistem pengelolaan pengiriman dan pengaturan barang menjadi efisien, tepat, dan aman (dengan memanfaatkan sistem informasi dan teknologi). Banyak Freight Forwarder bertindak sebagai operator dan bertanggung jawab penuh dalam melaksanakan pengangkutan meskipun tidak memiliki kapal sendiri. Yang dimaksud dengan operator disini adalah BHI (Badan Hukum Indonesia) yang melaksanakan kegitan usaha pelayanan jasa terhadap pesawat cargo dan barang dihanggar Bandar udara dalam rangka menunjang kegiatan angkutan melalui udara. Peran dan kegiatan perusahaan Freight Forwarding menjadi sangat penting karena memudahkan bagi para eksportir maupun importir dalam jasa pengurusan ekspor - impor. Kegiatan yang dilakukan Freight Forwarding merupakan satu kesatuan yang tidak dapat dihilangkan. Informasi dan strategi pengurusan dokumen dan cara pengiriman tersebut bertujuan untuk memberikan jasa pelayanan atau pengurusan atas seluruh kegiatan yang diperlukan bagi terlaksananya pengiriman, pengangkutan dan peneriman barang dengan menggunakan multimodal transport, baik melalui darat, laut atau udara.
\end{abstract}

Kata kunci : Asuransi; Barang Impor: Air Freight Forwading

\title{
A. PENDAHULUAN
}

Dalam era globalisasi saat ini, persaingan dan kompetensi dalam dunia bisnis dan perdagangan semakin kompetitif terlebih untuk perusahaanperusahaan yang berorientasi internasional. Bisnis internasional sendiri ialah yang kegiatannya melampaui batas-batas suatu negara. Banyak cara yang dilakukan untuk dapat berbisnis secara internasional, mulai dari kegiatan perdagangan/trading (ekspor, impor, subcontracting, counter trade), transfer (turnkey project, licencing, franchising), Foreign Direct Investment (FDI) di suatu negara seperti joint venture, contract manufacturing, management contranct, aliansi bisnis dan lainlain. Pada dasarnya bisnis internasional menjanjikan dan mampu meraih pasar yang luas, maka bisnis ini juga memiliki resiko yang cukup tinggi karena melibatkan banyak pihakpihak dengan berbagai kepentingan yang berbeda. Peran perusahaan jasa dalam bisnis ekspor impor sangat penting karena dapat memenuhi kebutuhan masyarakat yang telah melakuan bisnis dalam bidang perdagangan baik perdagngan domestik maupun perdagangan internasional karena kebanyakan pengusaha sulit untuk mengurus serta mengatur hal-hal yang terjadi di lapangan terutama pada saat barang mengalami masalah oleh karena itu pengusaha 
memerlukan jasa pelayanan yang bergerak di bidang ekspedisi atau yang juga di kenal dengan sebutan freight forwarder, yang dapat membantu pengusaha untuk menjadi perantara dalam mengurus semua kegiatan yang mencakup pengiriman,pengepakan, pengurusan dokumen dan lain-lain serta mengkoordinasikan barang mereka untuk sampai ke tujuan melalui jalur dan moda transportasi yang paling efisien. Freight forwarder sangat penting artinya bagi pengiriman barang umum sehingga ia dianggap sebagai physical distribution. Physical distribution dapat mencakup beberapa hal yang lainnya sudah di sebutkan diatas yang berhubungan dengan kegiatan logistik seperti transportasi, pengelolaan, pengiriman barang dengan kapal, gudang, pengepakan, penamaan, pengawasan terhadap kualitas, manajemen dan ketentuan- ketentuan bea cukai. Biasanya untuk membantu para importir khususnya dalam kegiatan importasi dibantu oleh suatu badan usaha yang bertujuan untuk meberikan jasa pelayanan atau pengurusan atas seluruh kegiatan yang diperlukan bagi terlaksananya pengiriman, pengangkutan, dan penerimaan barang dengan menggunakan Multimodal Transport, baik melalui darat, laut, dan udara yang biasa disebut Freight Forwarder.

Peranan penting dalam kegiatan ekspor impor yaitu sebagai perantara antara pengirim barang dengan penerima barang. Dengan adanya jasa pelayanan dari freight forwarder akan memudahkan para eksportir maupun importer dalam pengiriman dan penerimaan barang dari dalam negeri ataupun luar negeri. Sebuah jasa pengiriman cargo atau ekspedisi, bekerjasama dengan jasa asuransi untuk melindungi barang kiriman dari resiko kerusakan atau kehilangan. Banyak yang mengira jika jasa ekspedisi yang bertanggung jawab penuh dalam sebuah pengiriman, nyatanya tidak ada landasan hukum yang mengharuskan perusahaan ekspedisi bertanggung jawab terhadap barang yang rusak atau hilang. Manfaat Jasa Asuransi Dalam Pengiriman Barang, Jika berbicara soal ekspedisi atau jasa pengiriman barang dan cargo, pasti mayoritas orang selalu memikirkan bagaimana nasib barang yang akan dikirimkannya di perjalanan. Memang barang kiriman biasanya dipacking dengan proses packing berstandart, dan juga material yang digunakan dalam proses packing juga bermutu. Tetapi faktanya masih banyak konsumen yang khawatir soal keselamatan barang kiriman mereka. Oleh sebab itu diperlukanlah sebuah jasa asuransi yang khusus menjamin dan melindungi barang kiriman customer dari resiko kerusakan atau kehilangan selama dalam perjalanan. Jika anda mengasuransikan barang kiriman anda lewat jasa asuransi, maka hati anda bisa sedikit lebih tenang. Sebab jika terjadi hal-hal yang tidak diinginkan terhadap barang anda, anda akan mendapatkan premi terhadap barang anda tersebut. Barang-barang yang diasuransikan biasanya yang bernilai tinggi dan juga kendaran roda empat dan dua. 
Pemakaian asuransi ini bersifat opsional, tidak dipaksakan oleh jasa ekspedisi yang bersangkutan, melainkan diserahkan kepada customer apakah mau memakai asuransi atau tidak. Terdapat tiga kelompok asuransi barang yang terbagi sesuai jalur pengirimannya, yaitu asuransi cargo darat, asuransi cargo laut dan asuransi cargo udara. Asuransi pengiriman darat, melindungi barang kiriman dari bahaya yang terjadi secara tidak sengaja atau kecelakaan truk yang terjadi selama pengiriman jalur darat. Asuransi pengiriman laut, melindungi barang kiriman dari bahaya kecelakaan kapal tenggelam pada saat diperjalanan menuju tempat penerima. Asuransi pengiriman udara, memproteksi barang kiriman customer dari resiko yang terjadi di udara pada saat pengiriman barang via pesawat.

\section{B. LANDASAN TEORI}

Asuransi adalah suatu jaminan atau pertanggungan yang definisinya terdapat dalam K.U.H.D pasal 246 yang intinya adalah merupakan perjanjian antara penanggung (Asuransi) dengan tertanggung (Nasabah asuransi) dimana penggung, mengikatkan dirinya kepada tertanggung untuk memberikan ganti rugi seandainya tertanggung mengalami musibah dengan imbalan tertangggung diwajibkan untuk membayar sejumlah uang yang disebut dengan Premi.

Pihak - Pihak Dalam Asuransi

Dalam asuransi minimal ada 2 (dua) pihak yang mengadakan persetujuan/kontrak, yaitu :

1. Tertanggung

Disebut sebagai "insured" yaitu pihak yang mengalihkan risiko yang mungkin dihadapinya.

Kewajiban \& hak yang paling utama dari tertanggung adalah membayar premi sejumlah tertentu, serta mengajukan klaim kepada Penanggung apabila risiko yang dipertanggungkannya benar - benar terjadi.

2. Penganggung

Disebut juga sebagai Insured "atau"assurer" atau "underwrites", yaitu pihak yang menerima pengalihan risiko yang mungkin dihadapi oleh Tertanggung.

Hak dan kewajiban yang terutama dari sipenanggung adalah mendapatkan premi sejumlah tertentu serta memberikan penggantian kepada sitertanggung karena sesuatu kerugian kerusakan atau kehilangan keuntungan diharapkan, yang mungkin akan diderita.

Freight forwarder adalah badan usaha yang bertujuan untuk memberikan jasa pelayanan/pengurusan atas seluruh kegiatan yang diperlukan bagi terlaksananya pengiriman, 
pengangkutan dan penerimaan barang dengan menggunakan multimodal transport baik melalui darat, laut atau udara (Suyono:2005)

Aktivitas-aktivitas freight forwarding secara keseluruhan antara lain:

1. Memilih rute perjalanan barang, moda transportasi dan pengangkutan yang sesuai, kemudian memesan ruang kapal.

2. Melaksanakan penerimaan barang, menyortir, mengepak, menimbang berat, mengukur dimensi kemudian menyimpan barang kedalam gudang.

3. Mempelajari Letter of Credit barang, peraturan negara tujuan ekspor, negara transit, negara impor kemudian mempersiapkan dokumen-dokumen lain yang diperlukan.

4. Melaksanakan transportasi barang ke pelabuhan laut/udara, mengurus izin Bea dan Cukai, kemudian menyerahkan barang kepada pihak pengangkut.

5. Membayar biaya-biaya handling serta membayar freight.

6. Mendapat $\mathrm{B} / \mathrm{L}$ atau $\mathrm{AWB}$ dari pengangkutan.

7. Mengurus asuransi transportasi dan barang serta membantu mengajukan klaim kepada pihak asuransi bila terjadi kehilangan atau kerusakan atas barang.

8. Memonitor perjalanan barang sampai ke pihak penerima, berdasarkan info dari pihak pengangkut dan agen forwarder dinegara transit/tujuan.

9. Melaksanakan penerimaan barang dari pihak pengangkut.

10. Mengurus izin masuk Bea dan Cukai serta menyelesaikan bea masuk dan biayabiaya yang timbul di pelabuhan transit/tujuan.

11. Melakukan transportasi barang dari pelabuhan ke tempat penyimpanan barang gudang.

12. Melaksanakan penyerahan barang kepada pihak consignee dan melaksanakan pendistribusian barang bila diminta.

Peran Freight Forwarder a. Peran freight forwarder dalam konsolidasi muatan b. Peran freight forwarder sebagai pengangkut c. Peran freight forwarder dalam dokumentasi d. Peran freight forwarder dalam pembungkusan e. Peran freight forwarder dalam asuransi Hubungan freight forwarder dengan pihak ketiga dalam multimodal transport.

Konsolidasi muatan (cargo consolidation) atau juga disebut groupage, adalah pengumpulan beberapa kiriman barang dari beberapa eksportir atau shipper di tempat asal yang akan dikirimkan untuk beberapa consignee di tempat tujuan, yang dikemas dalam satu unit paket muatan, lalu muatan terkonsolidasi tersebut dikapalkan dan ditujukan ke agen 
konsolidator di tempat tujuan. Agen kemudian melaksanakan penyerahan barang kepada pihak consignee masing-masing. (Susilo:2008)

Menurut (Hutabarat:1997) Dalam transaksi perdagangan luar negeri yang lebih dikenal dengan istilah ekspor-impor pada hakikatnya adalah suatu transaksi yang sederhana dan tidak lebih dari membeli dan menjual baramg antara pengusaha-pengusaha yang bertempat di negara-negara yang berbeda. Namun dalam pertukaran barang dan jasa yang menyeberangi laut dan darat itu tidak jarang timbul berbagai masalah yang kompleks antara pengusahapengusaha yang mempunyai bahasa, kebudayaan,adat istiadat dan cara yang berbeda-beda. Dalam bidang impor, yang diperlukan untuk menunjang barang-barang ekspor tadi, umumnya yang diimpor adalah bahan baku industri, mesin-mesin, bahan-bahan kimia, ditambah dengan barang-barang modal untuk pelaksanaan pembangunan. Selain itu impor juga menyangkut bahan / barang kebutuhan konsumsi yang belum dapat di produksi dalam negeri.

Menurut (Purwito:2007) Instansi kepabeanan menyadari bahwa upaya penyimpangan, pemalsuan (fraud) dan penyelundupan terjadi di belahan dunia manapun, termasuk negara kita. Untuk itulah dalam meninkatkan efektifitas pengawasan dalam rangka mengoptimalkan pencegahan dan penindakan penyelundupan, perlu peraturan yang lebih jelas dalam pelaksanaaan kepabeanan.

Pihak-pihak yang Terlibat Freight Forwarder Untuk melaksanakan pekerjaan sehari harinya forwarder akan melibatkan stakeholder tertentu agar pekerjaan yang dilakukan dapat berjalan dengan lancar, mereka adalah: 1) Pemilik barang. 2) Pihak Stevedore atau di Indonesia disebut Perusahaan Bongkar Muat (PBM). 3) Cargo Surveyor pemeriksa barang di pelabuhan. 4) Asuransi dan Bank dalam hal dokumentasi dan keamanan barang serta sistem barang yang terkait. 5) Badan dan instansi pemerintah seperti: Bea Cukai, Kementerian Perdagangan, dan Kementerian Perhubungan.

Aktivitas Freight Forwarder. Aktivitas perusahaan freight forwarder dalam pengangkutan intermodal expor-impor menurut Suyono (2003) adalah: 1) Memilih rute perjalanan barang, moda transportasi dan pengangkutan yang sesuai, kemudian memesan ruang muat. 2) Melaksanakan penerimaan barang, menyortir, mengepak, menimbang berat, mengukur dimensi, kemudian menyimpan barang ke dalam gudang. 3) Mempelajari letter of credit barang, peraturan negara tujuan ekspor, negara transit, negara impor kemudian menyiapkan dokumen-dokumen lain yang diperlukan. 4) Melaksanakan transportasi barang ke pelabuhan laut atau udara, mengurus izin bea cukai, kemudian menyerahkan barang-barang kepada pihak pengangkut. 5) Membayar biaya-biaya handling serta membayarkan freight. 6) Mendapat bill 
of lading atau airway bill dari pihak pengangkut. 7) Mengurus asuransi transportasi barang dan membantu mengajukan klaim kepada pihak asuransi bila terjadi kehilangan atau kerusakan atas barang. 8) Memonitor perjalanan barang sampai ke pihak penerima, berdasarkan info dari pihak pengangkutan dan agen forwarding di negara transit atau tujuan. 9) Melaksanakan penerimaan barang dari pihak pengangkut. 10) Mengurus izin masuk pada Bea dan Cukai serta menyelesaikan bea masuk dan biaya-biaya yang timbul di pelabuhan transit atau tujuan. 11) Melaksankan transportasi barang dari pelabuhan ke tempat penyimpanan barang di gedung. 12) Melaksanakan penyerahan barang kepada pihak consignee, dan melaksanakan pendistribusian barang bila diminta.

Dalam (Daley:2000) Freight Forwarder dapat diklasifikasikan dan digolongkan sesuai dengan tingkat profesionalisme dalam melaksanakan proses penanganan dan pengiriman barang serta ketersediaan agen sebagai mitra usahanya di luar negeri. Berikut golongan freight forwarder: 1) Atas Dasar Operasional Jenis forwarder yang termasuk pada jenis ini adalah: Pengiriman barang oleh forwarder hanya dapat dilaksanakan dengan menggunakan sarana angkutan yang telah ditetapkan sebelumnya, yaitu dengan melihat bentuk, kemasan, berat, dan isi barang bersangkutan. 2) Atas Dasar Sarana Angkutan Jenis perusahaan freight forwarder atas dasar sarana angkutan adalah : a) Sea Freight Forwarder Kegiatan sea freight forwarder mengkhususkan kegiatan usahanya pada pengiriman barang muatan melalui angkutan laut atau melalui kombinasi antara angkutan darat lainnya b) Air Freight Forwarder Transportasi udara adalah komponen vital bagi banyak jaringan logistik internasional. Pengangkutan melalui jalur udara ini melibatkan integrasi informasi, transportasi, persediaan, pergudangan, penanganan material, dan kemasan. Lokasi kegiatan air freight forwarder berada di sekitar bandar udara, baik penyelesaian dokumen, penumpukan barang serta lalu lintasnya. c) Rail and Inland Freight Forwarder Rail and inland freight forwarder yaitu kegiatan usaha sektor angkutan darat dengan menggunakan jasa angkutan kereta api dan sarana angkutan lainnya. d) Combined Transport Operator Combined transport operator merupakan sarana angkutan freight forwarding yang mengkombinasikan laut, udara, kereta api dan truk.

Sistem kepabeanan di Indonesia menganut sistem self assessment, dimana importir diminta untuk memberitahukan di dalam pemberitahuan impor barang (PIB) berupa jumlah, jenis dan harga barang. Besar kecilnya pungutan negara sangat bergantung pula besarnya nilai pabean yang diberitahukan importir, sehingga pemberitahuan nilai pabean ini harus diteliti oleh Pejabat Bea dan Cukai. Tujuannya untuk menghindari pemberitahuan nilai pabean yang lebih rendah dari yang seharusnya, sehingga mengakibatkan kerugian penerimaan negara dari 
sektor bea masuk, cukai dan pajak dalam rangka impor. Penulis mengetengahkan 2 (dua) rumusan permasalahan. Pertama mengenai pengaturan bea masuk atas barang impor berdasarkan Undang-Undang Kepabeanan (UU. Nomor 17 Tahun 2006). Kedua mengenai akibat hukum dari pengaturan tarif bea masuk atas barang impor tersebut. Adapun tujuan penelitian ini adalah untuk mengetahui pengaturan dan akibat hukum dari tarif bea masuk atas barang impor berdasarkan Undang-Undang Kepabeanan. Pejabat Bea dan Cukai tetap diberi wewenang untuk meneliti dan menetapkan tarif dan nilai pabean untuk perhitungan bea masuk. Selain itu, tim audit juga mempunyai peran yang penting dalam meminimalisir kerugian negara.

Pengurusan pemberitahuan pabean atas barang impor dilakukan oleh pengangkut/importir. Dalam hal pengurusan pabean tidak dilakukan sendiri, importir dapat memberikan kuasanya kepada Pengusaha Pengurusan Jasa Kepabeanan (PPJK). Selain diatur dalam UU Kepabeanan, PPJK juga diatur dalam Peraturan Menteri Keuangan Nomor 65/PMK.04/2007 tanggal 20 Juni 2007 tentang Pengusaha Pengurusan Jasa Kepabeanan dan Peraturan Direktur Jenderal Bea dan Cukai Nomor P-22/BC/2007 tanggal 4 Juli 2007 tentang Petunjuk Pelaksanaan Pemberian Nomor Pokok dan Pengawasan Pengusaha pengurusan Jasa Kepabeanan. Terhadap barang impor dilakukan pemeriksaan pabean. Pada dasarnya pemeriksaan pabean dilakukan dalam daerah pabean, namun dengan mempertimbangkan kelancaran arus barang dan/atau pengamanan penerimaan negara, Menteri Keuangan dapat menetapkan pelaksanaan pemeriksaan pabean diluar daerah pabean oleh Pejabat Bea dan Cukai atau pihak lain yang bertindak untuk dan atas nama Direktorat Jenderal Bea dan Cukai.[6] Pemeriksaan pabean diatur dalam Pasal 3 Undang-Undang Nomor 10 Tahun 1995 tentang Kepabeanan sebagaimana telah diubah dengan Undang-Undang Nomor 17 Tahun 2006. Dalam pemeriksaan pabean juga dikenal beberapa penjaluran antara lain jalur merah, jalur hijau, jalur kuning, jalur MITA Non-Prioritas dan jalur MITA Prioritas.[7] Pemeriksaan pabean tidak hanya pemeriksaan fisik saja, melainkan juga pemeriksaan dokumen. Orang yang akan melakukan kewajiban pabean wajib melakukan registrasi ke Direktorat Jenderal Bea dan Cukai untuk mendapatkan nomor identitas dalam rangka akses kepabeanan.

\section{METODE PENELITIAN}

Penelitian ini menggunakan penelitian kualitatif. Penelitian ini menggunakan metode kualitatif, Moleong (2014) mendefinisikan penelitian kualitatif adalah jenis penelitian yang berusaha menggali informasi secara mendalam, serta terbuka terhadap segala tanggapan dan 
bukan hanya jawaban ya atau tidak. Penelitian ini mencoba untuk meminta orang-orang untuk mengungkapkan berbagai pikiran mereka tentang suatu topik tanpa memberi mereka banyak arahan atau pedoman bagaimana harus berkata apa. Menurut Sugiyono (2014) penelitian kualitatif adalah penelitian yang bermaksud untuk memahami fenomena tentang apa yang dialami oleh subjek penelitian misalnya perilaku, persepsi, motivasi, tindakan dan lain-lain., secara holistik, dan dengan cara deskripsi dalam bentuk katakata dan bahasa, pada suatu konteks khusus yang alamiah dengan memanfaatkan berbagai metode alamiah. Jenis penelitian yang digunakan dalam penelitian ini adalah analisis deskriptif dengan pendekatan kualitatif .

\section{PEMBAHASAN}

Prinsip-prinsip dasar penutupan asuransi yang akan diuraikan berikut ini merupakan dasar persetujuan asuransi yang harus diperhatikan dan dipenuhi oleh Tertanggung dan Penanggung serta merupakan prinsip yang mengikat kedua belah pihak, meskipun tidak dinyatakan secara tertulis dan Polis (Implied Conditions), yakni sebagai berikut :

\section{- Principle of Insurable Interest}

Menurut prinsip "Insurable Interst" dalam asuransi laut, Tertanggung hanya boleh melakukan penutupan asuransi atau objek pertanggungan apabila ia mempunyai kepentingan (Interst) atas objek terkasud secara terperinci, pihak yang mempunyai Insurable Interest atau suatu obyek pertanggungan ialah :

- Pemilik, secara otomatis mempunyai insurable interest terhadap barang dan kepentingan yang melekat didalamnya

- Orang yang dikuasakan pemilik untuk menguasaiatau mengawasi kepentingan tersebut (misalnya Consignee dan Freight Forwader)

- Orang/pihak yang memberikan kredit/pinjaman atau yang berurusan dengan pembayaran barang (misalnya Consignee dan Freight Forwader)

- Orang/pihak yang mempunyai tanggung jawab akibat dari adanya kontrak (misalnya perusahaan asuransi yang melakukan re-asuransi)

- Principle of Utmost Good Faith Menurut prinsip ini, penutupan asuransi baru dianggap berlaku/sah secara hukum apabila dilakukan atas dasar itikad baik dari kedua belah pihak yakni Tertanggung dan Penanggung. 
Karena asuransi adalah persetujuan tersebut haruslah dilakukan dengan jujur atau dilandaskan pada itikad baik.

Batalnya pertanggungan karena tidak memenuhi prinsip "Utmost Good Faith" antara lain diatur dalam pasal 251 KUHD yang berbunyi: "Setiap keterangan yang keliru atau tudak benar, ataupun setiap tidak memberitahukan hal - hal yang diketahui oleh pihak si Tertanggung betapapun itikad baik ada padanya, yang demikian sifatnya, sehingga, seandainya si Penaggung telah mengetahui keadaan yang sebenarnya, perjanjian tidak akan ditutup dengan syarat - syarat yang sama, mengakibatkan batalnya pertanggungan.

- Principle Value Menurut "Principle of Indemnity", perusahaan asuransi menjamin pihak Tertanggung jika terjadi risiko atas kepentingan yang diasuransikan akan mendapatkan ganti rugi.

Sudah jelas bahwa risiko yang terjadi terhadap barang atau kepentingan yang diasuransikan maka tidak akan ada tuntutan ganti rugi (claim) dari pihak Tertanggung kepada perusahaan asuransi yang bertindak sebagai Penanggungannya. Mengenai ketentuan beberapa besarnya ganti rugi dari Penanggung, harus diperhatikan hal - hal sebagai berikut :

- Insured Value Yaitu penutupan asuransi yang jumlah pertanggungannya semata mata didasarkan kepada nilai barang yang diasuransikan, penilaian mana terutama ditentukan oleh Tertanggung.

- Agreed Value Yaitu penutupan asuransi yang jumlah pertanggungannya ditentukan berdasarkan persetujuan kedua belah pihak, tanpa mempersoalkan apakah jumlah pertanggungan 'Over Insured' atau 'Under Insured'

Jasa Freight Forwarding menjamin bahwa produk akan sampai ke tujuan yang benar oleh disepakati tanggal, dan dalam kondisi baik. Layanan pengiriman barang memanfaatkan hubungan dibentuk dengan operator dari segala jenis, dari angkutan udara dan perusahaan truk, untuk angkutan keretaapi dan kapal laut. Jasa Freight Forwarding negosiasi harga terbaik untuk memindahkan produk sepanjang rute yang paling ekonomis dengan bekerja keluar berbagai tawaran dan memilih salah satu yang terbaik dari segi kecepatan, biaya dan keandalan.

Indonesia mengimpor barang-barang konsumsi bahan baku dan bahan penolong serta bahan modal. Barang-barang konsumsi merupakan barang-barang yang digunakan untuk 
memenuhi kebutuhan sehari-hari, seperti makanan, minuman, susu, mentega, beras, dan daging, bahan baku dan bahan penolong merupakan barang- barang yang diperlukan untuk kegiatan industri baik sebagai bahan baku maupun bahan pendukung, seperti kertas, bahanbahan kimia, obat-obatan dan kendaraan bermotor. Barang Modal adalah barang yang digunakan untuk modal usaha seperti mesin, suku cadang, komputer, pesawat terbang, dan alat-alat berat. produk impor indonesia yang berupa hasil pertanian, antara lain, beras, terigu, kacang kedelai dan buah-buahan. produk impor indonesia yang berupa hasil peternakan antara lain daging dan susu. Produk impor Indonesia yang berupa hasil pertambangan antara lain adalah minyak bumi dan gas, produk impor Indonesia yang berupa barang industri antara lain adalah barang-barang elektronik, bahan kimia, kendaraan. dalam bidang jasa indonesia mendatangkan tenaga ahli dari luar negeri. Semakin banyaknya dan pesatnya pertumbuhan perusahaan freight forwarding, maka semakin ketat pula persaingan antar perusahaan. Keberhasilan suatu perusahaan dicerminkan oleh kemampuan manajemen untuk memanfaatkan peluang secara optimal sehingga dapat menghasilkan penjualan dan laba sesuai dengan yang diharapkan. Keputusan yang diambil seorang manajer akan mempengaruhi suatu perusahaan di masa mendatang. Untuk mengetahui berapa permintaan periode berikutnya dan berapa jumlah produksi yang harus dikerjakan oleh suatu perusahaan maka seorang manajer harus dapat meramalkan permintaan atas produk yang dihasilkan untuk periode berikutnya. Dalam mengambil keputusan, manajer berusaha membuat estimasi dan perencanaan yang baik tentang apa yang terjadi di masa mendatang. Perencanaan yang efektif baik untuk jangka panjang maupun jangka pendek bergantung pada peramalan permintaan untuk produk/jasa tersebut.

\section{E. KESIMPULAN}

Perdagangan barang dan jasa antar negara terjadi karena kebutuhan barang dan jasa yang tidak dapat terpenuhi oleh suatu negara, dan negara tersebut dapat memperoleh barang atau jasa yang lebih murah atau lebih baik mutunya dari negara lain yang sering disebut kegiatan ekspor dan impor. Kegiatan impor mempunyai nilai ekonomi yang sangat penting bagi perkembangan industri itu sendiri maupun bagi negara. Impor adalah salah satu kegiatan perdagangan lintas batas negara dengan cara membeli produk dari dalam kawasan pabean suatu negara ke kawasan pabean negara lain. Perdagangan luar negeri terjadi karena adanya perbedaan barang-barang yang dihasilkan, biaya yang diperlukan serta mutu dan kualitasnya. Perdagangan internasional merupakan salah satu cara yang diperlukan bagi suatu negara 
untuk mencapai tujuan pembangunan nasionalnya. Dengan didukung kemajuan teknologi dan aksesbilitas transportasi yang semakin maju dewasa ini, membuat perpindahan barang atau jasa oleh setiap negara di dunia menjadi lebih cepat dan efisen. Arus informasi telah memungkinkan setiap negara lebih mengenal dan memahami negara lain. Dalam bidang ekonomi, setiap bangsa akan lebih mudah mengetahui dari mana barang-barang dapat diperoleh untuk memenuhi berbagai kebutuhannya dan sebaliknya kemana memasarkan produk-produk unggulannya. Peran Freight Forwarder Forwarder adalah tempat pemilik barang akan menerima nasehat dari forwarder tentang segala sesuatu terhadap berbagai aspekaspek dalam pengiriman dan pengangkutan barang:

1. Tata cara pengepakan atau pengemasan barang.

2. Negara tujuan pengiriman barang beserta meninjau peraturan-peraturan setempat.

3. Mengenai jalur dan rute angkutan barang yang terbaik dan tercepat.

4. Pengaturan dokumen dan pemantauan barang selama proses angkutan.

Di Indonesia telah banyak didirikan perusahaan-perusahaan yang bergerak di bidang perdagangan internasional. Baik secara langsung maupun menggunakan jasa perantara. Diantara jasa tersebut adalah Freight Forwading. Perusahaan ini menjadi perantara bagi perusahaan-perusahaan yang akan melakukan kegiatan impor. Pengurusan dokumen serta muatan yang masuk ke dalam kawasan pabean, importir biasanya menggunakan jasa Freight Forwading dalam pengiriman impor barang. Peran jasa Freight Forwading sangat membantu mempermudah importir dalam proses pengiriman barang, untuk masuk ke wilayah pabean negara Indonesia. Peran Freight Forwading bertujuan untuk memberikan jasa pelayanan atau pengurusan atas seluruh kegiatan impor yang diperlukan bagi terlaksananya pengiriman beserta dokumen-dokumen yang terkait dalam proses impor barang. Melengkapi dokumendokumen impor serta menyelesaikan biaya yang timbul sebagai akibat dari kegiatan penanganan muatan, serta pengurusan dokumentasi sampai barang keluar dari kawasan pabean. Berdasarkan hal tersebut, maka Freight Forwading dapat bertindak atas nama pihak yang menjadi penerima jasa penghubung antara importir dan bea cukai agar barang keluar dari wilayah pabean. 


\section{F. DAFTAR PUSTAKA}

Ali Purwito, 2007. Reformasi Kepabeanan, Yogyakarta, Graha Ilmu.

Sugiyono. 2012. Metode Penelitian Kuantitatif Kualitatif dan R\&D. Bandung: Alfabeta.

Moleong, Lexy J, 2014, Metodologi Penelitian Kualitatif. Bandung:PT Remaja Rosdakarya.

Murphy, Paul. R. dan James. M. Daley 2000. An Empirical Study of Interner Issues among International Freight Forwarders. Transportation Jurnal.

Roselyne Hutabarat, 1997. Transaksi Ekspor-Impor, Jakarta: Erlangga.

Suyono,R.P.,(2005).Shipping:Pengangkutan Intermodal Ekspor Impor Melalui Laut, Penerbit PPM

Susilo, Andi. 2008. Buku Pintar Ekspor Impor. Jakarta : TransMedia.

Undang-Undang Kepabeanan (UU. Nomor 17 Tahun 2006).

Peraturan Direktur Jenderal Bea dan Cukai Nomor P-22/BC/2007 tanggal 4 Juli 2007

Peraturan Menteri Keuangan Nomor 65/PMK.04/2007 tanggal 20 Juni 2007 tentang Pengusaha Pengurusan Jasa Kepabeanan 